\title{
Study on Tao Xingzhi's Practice of Altruism and Its Contemporary Value
}

\author{
Liuqi Wang \\ Nanyang Institute of Technology \\ Nanyang, China 473004
}

\begin{abstract}
Altruism, as an important contemporary social trend of thought, has aroused widespread concern in the academic community. It is conducive to the construction of a better harmonious society by in-depth study and examination of altruism. Tao Xingzhi, as a great educator in China, has perfectly interpreted altruism with his own practice and experience, which can be regarded as the model of intellectuals in China and even in the world.
\end{abstract}

Keywords-humanity; altruism; educational activities; Tao Xingzhi; practice; value

\section{INTRODUCTION}

Altruism, as an important contemporary social trend of thought, emphasizes that social interests should be put above personal interests. Also, it would sacrifice their own interests for the interests of others and society. This proposal is undoubtedly the same as the construction of today's harmonious society. In-depth study and survey on altruism can provide certain reference for the construction of harmonious society. Tao Xingzhi, as an outstanding educator of China, has perfectly interpreted altruism with his own practice and experience. Also, it has set a good example for the whole human society.

\section{THE PROPOSITION OF ALTRUISM AND ITS INFLUENCE ON CHINESE MODERN CULTURAL AND INTELLECTUAL CIRCLES}

Altruism is based on the deepening understanding of human nature. Throughout the ages, the debate about human nature can be said to be long-standing. In China, Mencius advocated that man should be good in nature. Xunzi believed that man should be evil in nature. And Gaozi emphasized that human nature is indifferent to good and evil. And he put forward the eclectic theory of good nature and evil nature. In the West, from Plato's ideal country to Rousseau's social contract theory, people are essentially kind. The friendship, mutual help, cooperation and harmony are the basis of human nature. And noble morality is the product of human innate instinct and nurture. From the ancient Greek philosophy of sophistry to Malthusian theory of population, and then to Darwin's theory of evolution, they all believe that self-interest is the nature of human beings. Human moral sense derives from human social instinct, where acquired education plays a decisive role.
On this basis, French positivist philosopher in the 19th century, Conde created the word "altruism", which is a kind of ethics to praise the noble spirit and moral character of making sacrifices for others. And it is the criterion of human behavior. Also, it is the criterion to judge the good and evil human nature. Altruism contrasts with egoism. Altruism is an ethical doctrine that puts social interests above personal interests and sacrificing one's own interests for the benefit of others and society. It is also a behavioral principle and attitude towards life.

After the emergence of altruism, it soon spread all over the world. And it has produced a widespread and farreaching impact on human society. The intellectual circle of modern Chinese culture is also deeply influenced by altruism. At the beginning of the 20th century, China was suffering from internal and external problems. Under the influence of altruism, many wise people in the cultural and intellectual circles were involved in the tide of saving the country and the people. Taking the rural education in China at that time as an example, in order to seek the country's prosperity and realize the ideal of saving the country with science and education, many educators gave up all kinds of temptations and opportunities, started with improving the quality of peasants, and then improved the quality of all the people. They went to the countryside one after another to carry out educational reform experiments, vigorously advocated and devoted themselves to the rural education. For example, in the early years of the Republic of China, Huang Yanpei, a well-known educator, twice refused to serve as the chief education officer of the Beiyang government. And he determined to engage in ordinary vocational education. Yan Yangchu, a graduate of Yale University in the world, declined to go to the Foreign Ministry of Beiyang Government, and devoted himself to the education of the common people. Liang Shuming, who had been living in a big city since childhood, was willing to resign his attractive teaching post as a professor of Peking University, the highest university in China, and was willing to give way to a middle school in Cao County in the southwest of Shandong Province. $\mathrm{Yu}$ Ching-tang, a graduate of Columbia University's Teachers College in the United States, volunteered to resign as the Dean of the Jiangsu Provincial Institute of Education and was willing to be an ordinary teaching researcher. All these educators aspire not to be officials. And they devoted themselves to the mass education cause. [1] They do it entirely for the benefit of others and society. And they are 
faithful practitioners of altruism. Among them, Tao Xingzhi is undoubtedly the most outstanding representative of practicing altruism.

Tao Xingzhi, as a representative of outstanding overseas returnees at the time, studied from famous philosopher and educator Dewey. After returning home, he could teach at a higher education institution and live a life of ease and enjoyment. However, in order to make the country rich and strong. In 1926, he abandoned the rich life of the university professor, and resolutely threw himself into the civilian class of the time. When he was a professor at a university, he earned 300 yuan a month. It is certain that if Tao Xingzhi only cared about personal promotion and wealth, he could maintain his status as a "senior Chinese". Also, he could get the promotion step by step. However, Tao Xingzhi, who wanted to enable the Chinese common people to receive education, was not in high-ranking officials and great wealth. In various names, he resigned from important posts such as the headmaster of Wuchang Higher Normal School and the director of education in Henan and Anhui. Without hesitation, he threw himself into the embrace of the masses and became a respected mentor.

\section{TAO XINGZHI'S PRACTICE OF AltRUiSM}

Tao Xingzhi is a great educator and educational thinker in modern China. Also, he is a model of progressive intellectuals in China. He embodies the valuable qualities of the excellent Chinese intellectuals, loves the motherland and the people, and lives for others. All of this is a true portrayal of Tao Xingzhi's brilliant life. And he vividly interprets altruism for people with his own practice and experience.

\section{A. "To Come with a Heart, and to Leave without Half a Root of Grass"}

Tao Xingzhi lived in a time when the country was in trouble. And saving the nation was the top priority at that time. As an outstanding representative of modern Chinese intellectuals, he resolutely threw himself into the great tide. "To come with a heart and to leave without half a root of grass" is Tao Xingzhi's life aphorism. In Tao Xingzhi's ordinary education career, he has made an immortal contribution.

From an early age, Tao Xingzhi set up the grand ambition that "I am a Chinese, and I should make some contributions to China" [2]. When he went to study in the United States, his heart was tied to his motherland. And he had just completed his years of study. He set foot on his way home. After returning to China, Tao Xingzhi gave up all his achievements and benefits. He wanted to explore a way to save the nation and the people. And he took an active participation in educational practice. After the September 18th Incident, the national crisis in China had been deepened. He conscientiously combined education with the patriotic struggle for national liberation, and actively threw himself into and appealed to the whole society to take part in the struggle against Japanese aggression and national salvation. After the July 7th Incident, Tao Xingzhi held anti-Japanese education and difficult education, and spared no effort to mobilize all the forces of the country to fight against the national disaster. After the War of Resistance against Japan, Tao Xingzhi led the people to rise against the civil war, opposed the fascist dictatorship and the Kuomintang government's anti-people's civil war policy, and welcomed the arrival of independence, peace, democracy, and a bright new China with high morale and fighting stance. These real educational practice activities show the unremitting pursuit of patriotic intellectual.

As a patriotic intellectual, Tao Xingzhi's greatest aspiration in his life was "to make the whole nation have the opportunity to receive education". And his life-long educational practice showed that he faithfully fulfilled his promise. In order to realize this ambition, Tao Xingzhi went out of the institutions of higher learning envied by others. He organized the Association for the Promotion of Civilian Education, and carried on the spirit of patriotism for the people, and called on more than ten provinces and cities, including Hebei, Henan, Inner Mongolia, Jiangsu, Zhejiang, Jiangxi, and Hubei. His footprints are all over the north and south of the Great Rivers. He worked hard, and achieved remarkable results. The cultural quality of the people at that time has been improved to a certain extent.

Tao Xingzhi's educational practice is characterized by serving the working masses wholeheartedly. He has opened schools for the laborious masses. And it is the driving force to make him move forward. When he was a child, his family was poor. And he had a taste of the difficulty of going to school. And he knows that it is not easy for the laborious masses to have study. Therefore, he devoted himself to saving the country and the people. Also, he devoted his life to running schools for the laborious masses and their children. One of the fundamental principles of Tao Xingzhi's education is to uphold the people's supremacy and serve the people. As a university professor, he was keen to engage in civilian education. And he went to the countryside to set up Xiaozhuang Teachers College. The purpose was to transform the rural areas of China, and to cultivate rural teachers with scientific mind, the skills of farmers and transforming the society. Later, he founded Chongqing Social University. Taking the method of spare-time study, those poor young people can have their jobs. And they would also have the opportunity to learn. The university teaches people to show that everyone has his or her own virtue. Everyone can remove pollution and reform, and strive for excellence. In the end, they would achieve the perfect effect. [3] Tao Xingzhi's idea of running a school for the people is precisely his self-portrayal. "We should learn from the people, report to the people, serve the people, call on behalf of the people, teach people to make the progress, and guide the people. And this would become the university for people. [4]

Tao Xingzhi devoted all his life to education. It is from the education of the common people, the education of the country, the education of the masses to the education of democracy. He unswervingly took universal education as his duty. However, he had no desire for it. He is worthy of a great educator and the mentor for the people. Altruism is vividly reflected in his body. 


\section{B. "Love Fills the World"}

Tao Xingzhi lived his life with the motto of "love is all over the world". And he practiced it with his own actual action. He said, "We are fighting with love, not force." [5] In his opinion, love means a kind of power. Noble and pure teacher-student relationship is more likely to arouse the strong resonance of the students' hearts. And then, it would obtain the best educational results. Tao Xingzhi loves his students more than his own children. If the student had no money to study, he took out his own money to help him. When the student was arrested, he tried everything he could to rescue him. He has always treated the students equally. And he never favors them. He wouldn't judge people by their family and looks. It can be said that he has really achieved the goal of "teaching without discrimination." He often encouraged himself with the idea of "loving the whole world". He wanted his laborious children to become pupils in pursuit of truth, and to become self-conscious little gentlemen, small workers with both hands and brains, and small soldiers who resisted aggression. And then, it would realize his desire to build a nation. Tao Xingzhi's "love" is a great and noble emotion. It is not a simple vulgar love.

Tao Xingzhi said in his "My View of School": "I have a sentence to advise school comrades. This sentence is "to treat students like children." [6] What he did is same to what he said. In life, Tao Xingzhi gave the students meticulous care. However, in the study and management, he had strict requirements. His principle of management is that the freedom should be relative to the strictness. To the students, he is the father first. A student who is hungry, thirsty or ill, is willing to find him and talk to him. However, he held fast to the moral requirements of his students. If a classmate harms the masses, he gives severe criticism. He cared for every student. And he worked day and night for them. He was just like a gardener. And he strives to "teach thousands of people to seek truth". [6] All these reflect Tao Xingzhi's selfless love for others and society. Tao Xingzhi set a good example for human teachers with his practical actions. Also, it vividly annotated altruism.

\section{THE CONTEMPORARY VALUE OF TAO XINGZHI'S ALTRUISM SPIRIT}

With the deepening understanding and research on altruism, altruism has been strongly advocated and eulogized in the world. To a certain extent, it has inhibited the further expansion of extreme egoism. Altruism is undoubtedly a progressive behavior value here. However, we should do comprehensive and in-depth understanding and analysis on the altruism. The traditional altruism completely ignored personal interests. And then, it would fall into the ethical dilemma of morality and interests, altruism and self-interest. Today, with the economic globalization and cultural diversity, it has involved individuals, enterprises, society, the country and other multiple relations, as well as economic, ethical, legal, political and many other factors. Therefore, it should have more comprehensive and more in-depth study of altruism. And the analysis of interests and morality, selfinterest and altruism as well as the relationship between individuals and collectives is necessary. To suppress extreme egoism and resolve social contradictions and conflicts is necessary. Also, the reconstruction of ethical norms and socialist harmonious society is particularly important.

\section{CONCLUSION}

Tao Xingzhi, as a model of excellent intellectuals and educationists in China, has practiced altruism vividly with his own actual action. With his extensive knowledge, enthusiasm for serving the people, and the spirit of persevering to the end, he assiduously explored the path of China's educational development. And he also made outstanding contributions to the educational cause for the Chinese people. As Lu Dingyi said, Tao Xingzhi "devoted his life to the cause of saving the country, the cause of democracy and the cause of education. And his contribution to education is particularly great and indelible." [7] Mao Zedong called him "the great educator". And Song Qingling praised him as "the teacher's representative of all ages". It fully showed that Tao Xingzhi's altruistic educational practice was respected and affirmed by the people. This is the expectation of altruism to human society. And it is beneficial to the construction of human community and the promotion of long-term peace and development of the world.

\section{REFERENCES}

[1] Miao Chunde. China's modern rural education history [M]. Beijing: People's Education Press. 苗春德.中国近现代乡村教育史 [M].北 京: 人民教育出版社

[2] Tao Xingzhi's Complete Works (Vol. 1) [M]. Changsha: Hunan Education Publishing House. 陶行知全集（第一卷） [M].长沙： 湖南教育出版社

[3] Tao Xingzhi's Complete Works (Vol. 3) [M]. Changsha: Hunan Education Publishing House. 陶行知全集（第三卷） [M].长沙： 湖南教育出版社

[4] Tao Xingzhi's Complete Works (Vol. 4) [M]. Changsha: Hunan Education Publishing House. 陶行知全集（第四卷） [M].长沙: 湖南教育出版社

[5] Tao Xingzhi's Complete Works (Vol. 2) [M]. Chengdu: Sichuan Education Press. 陶行知全集（第二卷） [M].成都: 四川教育出 版社

[6] Tao Xingzhi's Complete Works (Vol. 5) [M]. Chengdu: Sichuan Education Press. 陶行知全集 (第五卷) [M].成都: 四川教育出 版社

[7] Mourning Tao Xingzhi, people's educator [N]. The Liberation Daily (Yan'an), August 27, 1946. 悼人民教育家陶行知先生 [N].1946 年 8 月 27 日, 解放日报 (延安) 